Article

\title{
Evaluating the Potential Value of Natural Product Cuminic Acid against Plant Pathogenic Fungi in Cucumber
}

\author{
Yong Wang ${ }^{\dagger}$, Jie Zhang ${ }^{\dagger}$, Yang Sun, Juntao Feng and Xing Zhang * \\ Research and Development Center of Biorational Pesticides, Northwest A \& F University, \\ Yangling 712100, China; wy2010102163@163.com (Y.W.); deit1984@sina.com (J.Z.); \\ Sunyang136592@nwsuaf.edu.cn (Y.S.); jtfeng@126.com (J.F.) \\ * Correspondence: zhxing1952@126.com; Tel./Fax: +86-029-8709-2122 \\ t These authors contributed equally to this work.
}

Received: 4 September 2017; Accepted: 1 November 2017; Published: 6 November 2017

\begin{abstract}
Fusarium wilt and anthracnose are two major diseases which limit the yield and quality of cucumber worldwide. Cuminic acid was extracted from the seed of Cuminum cyminum L. The mean $\mathrm{EC}_{50}$ values of cuminic acid for inhibiting mycelial growth and zoospore germination of five Fusarium oxysporum f. sp. cucumerinum strains were $25.66 \pm 3.02 \mu \mathrm{g} / \mathrm{mL}$ and $15.99 \pm 2.19 \mu \mathrm{g} / \mathrm{mL}$, and of four Colletotrichum lagenarium (Pass.) Ellis and Halsted strains were $29.53 \pm 3.18 \mu \mathrm{g} / \mathrm{mL}$ and $18.41 \pm 2.78 \mu \mathrm{g} / \mathrm{mL}$, respectively. In greenhouse experiments, cuminic acid at $2000 \mu \mathrm{g} / \mathrm{mL}$ exhibited $70.77 \%$ protective and $62.63 \%$ curative efficacies against $F$. oxysporum, and $65.43 \%$ protective and $55.46 \%$ curative efficacies against $C$. lagenarium. Moreover, the translocation behavior of cuminic acid, determined by high performance liquid chromatography (HPLC), showed that it could be readily absorbed and transported upward and downward in cucumber. Importantly, superoxide dismutase (SOD) and pyphenol oxidase (PPO) activities of cucumber leaves treated with cuminic acid increased significantly. All results indicated that cuminic acid showed antifungal activity, and could be used as a botanical fungicide in disease management. This study encourages further investigation on the mechanism of action of cuminic acid and the development of alternative antifungal drugs.
\end{abstract}

Keywords: botanical fungicide; cuminic acid; cucumber; F. oxysporum; C. lagenarium; control efficacy

\section{Introduction}

Cucumber is one of the most important vegetables grown in the world, especially in China. Fusarium wilt, a soil-borne disease caused by F. oxysporum, and anthracnose, which is caused by C. lagenarium, are the main diseases that limit the yield and quality of cucumber worldwide $[1,2]$. Stems and roots, and especially root wounds, can be infected by F. oxysporum. The chlamydospores generated by F. oxysporum can survive in infested field soil for several years [3]. On the other hand, all above-ground tissues of cucumber, such as leaves, stems, petioles, and fruits, can be infected by C. lagenarium [4].

In practice, the application of chemical fungicides is still the main method used for disease management in cucumber due to the limit of highly resistant cultivars [5,6]. However, widespread use of these chemical fungicides has generated serious problems, including cost, environmental pollution, decreased efficacy due to pathogen resistance, and threats to human health [7,8]. Therefore, screening for alternative fungicides that do not harm people or the environment is urgently necessary. Considering the requirements of modern greenhouse agriculture, botanical fungicides have attracted more attention. Indeed, the practice of using botanical fungicides, or plant extracts as we know them in agriculture, dates back at least two millennia in many countries, such as ancient China, Greece, 
India, Egypt, and North America [9]. Botanical fungicides have certain advantages: They usually break down rapidly and do not persist in the environment, and have a low risk of inducing pathogen resistance. Moreover, botanical fungicides can also be used as lead compounds for the synthesis of novel compounds $[10,11]$.

Cuminic acid was extracted from the seed of Cuminum cyminum L. in our previous research [12]. Cuminic acid belongs to the benzoic acid chemical group. Previous studies have shown that cuminic acid exhibits obvious antifungal activity against several plant pathogens, such as Phytophthora capsici Leonian, Rhizoctonia cerealis E.P. van der Hoeven, and Sclerotinia sclerotiorum (Lib.) de Bary. The mycelial growth of $S$. sclerotiorum and $R$. cerealis was completely inhibited when treated with cuminic acid at $200 \mu \mathrm{g} / \mathrm{mL}[13,14]$. Moreover, in greenhouse experiments, more than 50\% efficacy against S. sclerotiorum and Blumeria graminis $\mathrm{f}$. sp. tritici was obtained when plants were treated with cuminic acid at $1000 \mu \mathrm{g} / \mathrm{mL}$, which was comparable with the efficacy of procymidone at $100 \mu \mathrm{g} / \mathrm{mL}$ [13]. Moreover, the $\mathrm{EC}_{50}$ value of cuminic acid for inhibiting the mycelial growth of $P$. capsici was only $14.54 \mu \mathrm{g} / \mathrm{mL}$, which was even lower than the $\mathrm{EC}_{50}$ value of the natural compound eugenol against P. capsici [12].

Cuminic acid has demonstrated broad-spectrum antifungal activity. However, few reports about the antifungal activity of cuminic acid against F. oxysporum or C. lagenarium are available in the literature. Therefore, the aim of this study was to evaluate the potential value of the natural compound cuminic acid, extracted from the seed of Cuminum cyminum L., as a botanical fungicide against F. oxysporum or C. lagenarium.

\section{Results}

\subsection{Sensitivity to Cuminic Acid}

There was significant difference $(p=0.05)$ in sensitivity to cuminic acid between strains (Table 1$)$. The $\mathrm{EC}_{50}$ values for the inhibition of mycelial growth for the five F. oxysporum strains and four C. lagenarium strains by cuminic acid ranged from 18.46 to $32.34 \mu \mathrm{g} / \mathrm{mL}$ and 22.45 to $35.71 \mu \mathrm{g} / \mathrm{mL}$, with mean $\mathrm{EC}_{50}$ values of 25.66 and $29.53 \mu \mathrm{g} / \mathrm{mL}$, respectively. The $\mathrm{EC}_{50}$ values for the inhibition of spore germination of the five F. oxysporum strains and four C. lagenarium strains by cuminic acid ranged from 13.37 to $18.22 \mu \mathrm{g} / \mathrm{mL}$ and 17.44 to $20.45 \mu \mathrm{g} / \mathrm{mL}$, with mean $\mathrm{EC}_{50}$ values of 15.99 and $18.41 \mu \mathrm{g} / \mathrm{mL}$, respectively. However, the $\mathrm{EC}_{50}$ values for cuminic acid were always higher than that of carbendazim, for both inhibiting mycelial growth and spore germination (Table 1).

Table 1. Sensitivity to cuminic acid and carbendazim.

\begin{tabular}{|c|c|c|c|c|}
\hline \multirow{2}{*}{ Strains ${ }^{a}$} & \multicolumn{2}{|c|}{$\begin{array}{l}E_{50} \text { for Cuminic Acid } \\
\qquad(\mu \mathrm{g} / \mathrm{mL})\end{array}$} & \multicolumn{2}{|c|}{$\begin{array}{c}\mathrm{EC}_{50} \text { for Carbendazim } \\
(\mu \mathrm{g} / \mathrm{mL})\end{array}$} \\
\hline & $\begin{array}{c}\text { Inhibition of } \\
\text { Growth }\end{array}$ & $\begin{array}{l}\text { Inhibition of } \\
\text { Germination }\end{array}$ & $\begin{array}{l}\text { Inhibition of } \\
\text { Growth }\end{array}$ & $\begin{array}{l}\text { Inhibition of } \\
\text { Germination }\end{array}$ \\
\hline FO-1 & $21.37 c^{b}$ & $15.62 b$ & $0.900 \mathrm{~b}$ & $1.173 c$ \\
\hline FO-23 & $25.62 c$ & $13.37 \mathrm{c}$ & $1.211 b$ & $1.432 \mathrm{c}$ \\
\hline FO-12 & $18.46 \mathrm{~d}$ & $16.02 \mathrm{ab}$ & $0.794 b$ & $0.983 c$ \\
\hline FO-14 & $32.34 \mathrm{ab}$ & 16.73ab & $0.869 b$ & $0.874 \mathrm{c}$ \\
\hline FO-8 & $30.50 \mathrm{~b}$ & $18.22 \mathrm{a}$ & $1.001 \mathrm{~b}$ & $0.992 \mathrm{c}$ \\
\hline CL-32 & $22.45 c$ & $18.36 a$ & $7.322 \mathrm{a}$ & $6.406 a$ \\
\hline CL-12 & $35.71 \mathrm{a}$ & $19.43 a$ & $6.537 a$ & $6.035 a$ \\
\hline CL-7 & $30.09 b$ & $17.44 \mathrm{a}$ & $5.459 a$ & $4.941 b$ \\
\hline CL-11 & $29.87 \mathrm{~b}$ & $20.45 a$ & $6.344 a$ & $6.075 a$ \\
\hline
\end{tabular}

Note: ${ }^{a} \mathrm{FO}$, F. oxysporum; CL, C. lagenarium; ${ }^{\mathrm{b}} \mathrm{a}, \mathrm{b}, \mathrm{c}, \mathrm{d}$ mean values followed by the different letter within the same column were significantly different in least significant difference (LSD) tests at $p=0.05$. 


\subsection{Protective and Curative Activity of Cuminic Acid}

Protective and curative activities of cuminic acid against $F$. oxysporum and C. lagenarium were determined in a greenhouse. The results showed that cuminic acid exhibited both protective and curative activities against both F. oxysporum and C. lagenarium. When treated with cuminic acid at $2000 \mu \mathrm{g} / \mathrm{mL}$, the protective efficacies against F. oxysporum and C. lagenarium were $70.77 \%$ and $65.43 \%$, respectively, which were even better or nearly equal to the efficacy attained by carbendazim at $500 \mu \mathrm{g} / \mathrm{mL}$ (Tables 2 and 3). Moreover, the protective and curative efficacies of cuminic acid at 1000 and $2000 \mu \mathrm{g} / \mathrm{mL}$ against $F$. oxysporum were always higher than those against C. lagenarium treated with cuminic acid at the same concentration. The protective efficacies were always higher than curative efficacies whether treated with cuminic acid at 500, 1000 or $2000 \mu \mathrm{g} / \mathrm{mL}$ (Figures 1 and 2). This indicates that cuminic acid not only has a better protective than curative activity, but also has better antifungal activity against $F$. oxysporum than C. lagenarium.

Table 2. Protective and curative activity of cuminic acid against F. oxysporum.

\begin{tabular}{ccccc}
\hline \multirow{2}{*}{ Treatment } & \multicolumn{2}{c}{ Protective Activity } & \multicolumn{2}{c}{ Curative Activity } \\
\cline { 2 - 5 } & Disease Index & Efficacy (\%) & Disease Index & Efficacy (\%) \\
\hline Cuminic Acid $(500 \mu \mathrm{g} / \mathrm{mL})$ & $66.67 \mathrm{~b}^{\mathrm{a}}$ & $26.16 \mathrm{c}$ & $68.06 \mathrm{~b}$ & $23.43 \mathrm{c}$ \\
Cuminic Acid $(1000 \mu \mathrm{g} / \mathrm{mL})$ & $51.39 \mathrm{c}$ & $43.08 \mathrm{~b}$ & $50.00 \mathrm{c}$ & $43.75 \mathrm{~b}$ \\
Cuminic Acid $(2000 \mu \mathrm{g} / \mathrm{mL})$ & $26.39 \mathrm{~d}$ & $70.77 \mathrm{a}$ & $33.22 \mathrm{~d}$ & $62.63 \mathrm{a}$ \\
Carbendazim $(500 \mu \mathrm{g} / \mathrm{mL})$ & $27.78 \mathrm{~d}$ & $69.22 \mathrm{a}$ & $34.70 \mathrm{~d}$ & $60.96 \mathrm{a}$ \\
Water Control & $90.28 \mathrm{a}$ & - & $88.89 \mathrm{a}$ & - \\
\hline
\end{tabular}

Note: ${ }^{a} a, b, c, d$ mean values followed by the different letter within the same column were significantly different in LSD tests at $p=0.05$.

Table 3. Protective and curative activity of cuminic acid against C. lagenarium.

\begin{tabular}{ccccc}
\hline \multirow{2}{*}{ Treatment } & \multicolumn{2}{c}{ Protective Activity } & \multicolumn{2}{c}{ Curative Activity } \\
\cline { 2 - 5 } & Disease Index & Efficacy (\%) & Disease Index & Efficacy (\%) \\
\hline Cuminic Acid $(500 \mu \mathrm{g} / \mathrm{mL})$ & $42.80 \mathrm{~b}$ & $21.77 \mathrm{c}$ & $36.01 \mathrm{~b}$ & $17.07 \mathrm{c}$ \\
Cuminic Acid $(1000 \mu \mathrm{g} / \mathrm{mL})$ & $32.92 \mathrm{c}$ & $39.85 \mathrm{~b}$ & $29.01 \mathrm{c}$ & $33.18 \mathrm{~b}$ \\
Cuminic Acid $(2000 \mu \mathrm{g} / \mathrm{mL})$ & $18.93 \mathrm{~d}$ & $65.43 \mathrm{a}$ & $19.34 \mathrm{c}$ & $55.46 \mathrm{a}$ \\
Carbendazim $(500 \mu \mathrm{g} / \mathrm{mL})$ & $18.31 \mathrm{~d}$ & $66.55 \mathrm{a}$ & $16.05 \mathrm{c}$ & $63.04 \mathrm{a}$ \\
Water Control & $54.73 \mathrm{a}$ & - & $43.42 \mathrm{a}$ & - \\
\hline
\end{tabular}

Note: ${ }^{\mathrm{a}} \mathrm{a}, \mathrm{b}, \mathrm{c}, \mathrm{d}$ mean values followed by the different letter within the same column were significantly different in LSD tests at $p=0.05$.
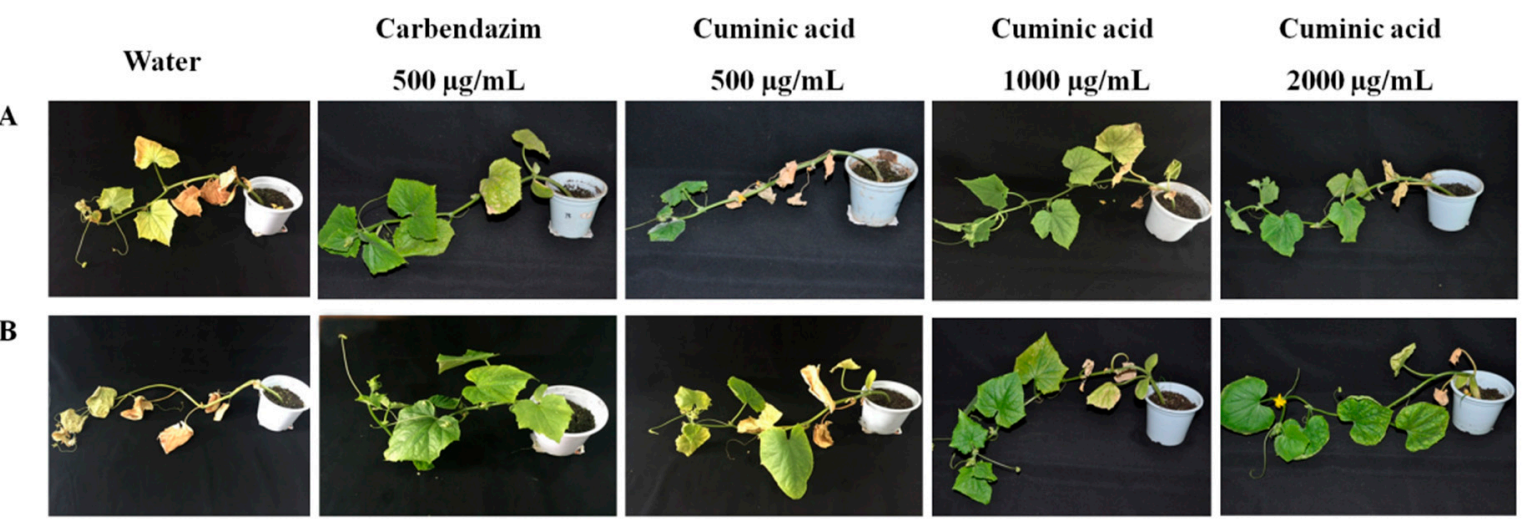

Figure 1. (A) Protective and (B) curative activity of cuminic acid against F. oxysporum. 

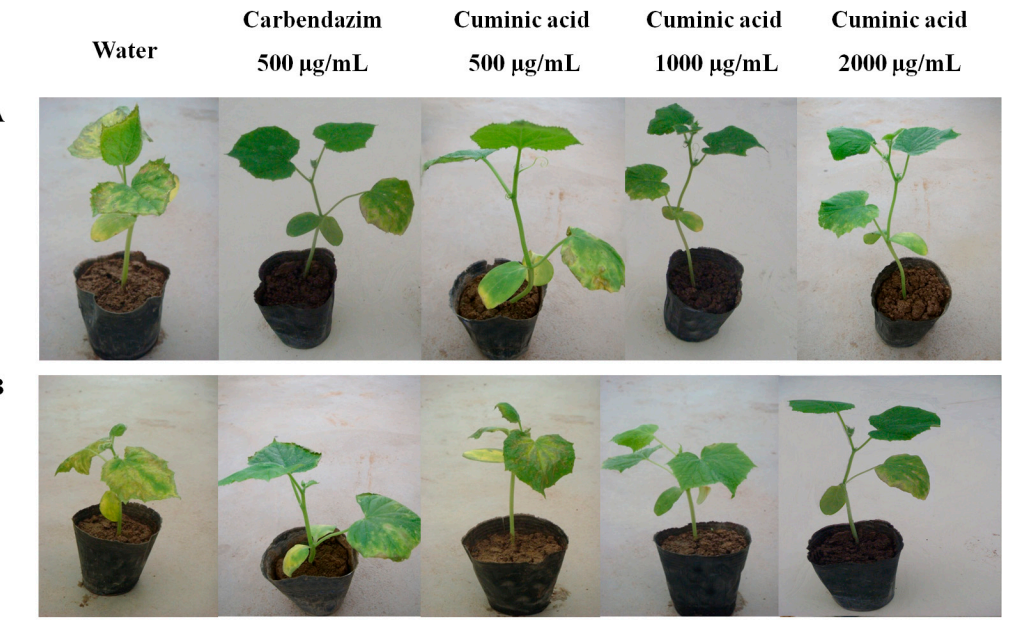

Figure 2. (A) Protective and (B) curative activity of cuminic acid against C. lagenarium.

\subsection{Translocation Behavior of Cuminic Acid}

As shown in Figure 3, the standard product of cuminic acid was detected after $10 \mathrm{~min}$ using liquid chromatography. As expected, cuminic acid was detected in both the roots of the cucumber plants sprayed with cuminic acid and the leaves of the cucumber plants irrigated with cuminic acid at the same time. LC-MS data for cuminic acid is shown in the supplementary materials. These results suggest that cuminic acid could be absorbed and translocated both upward and downward in cucumber plants.

A

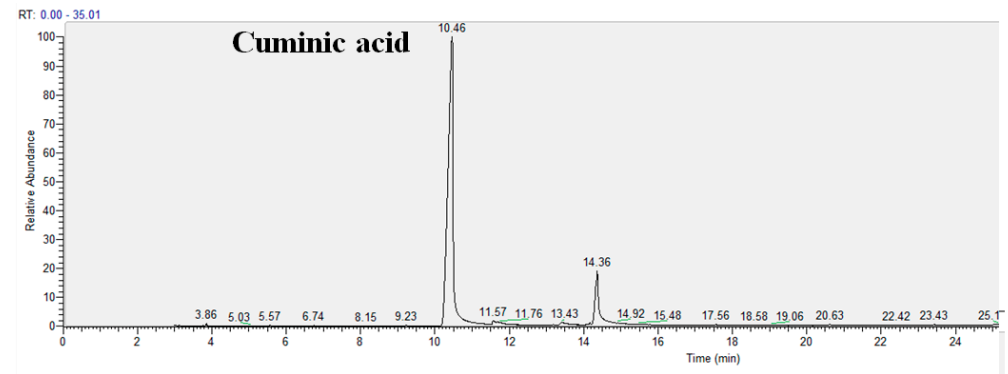

B

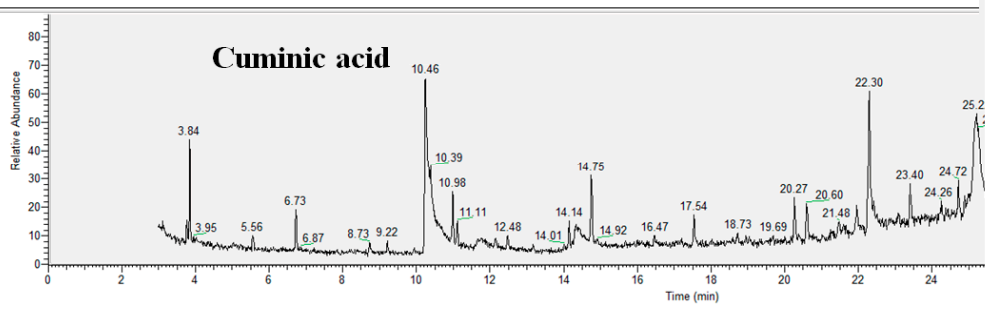

C

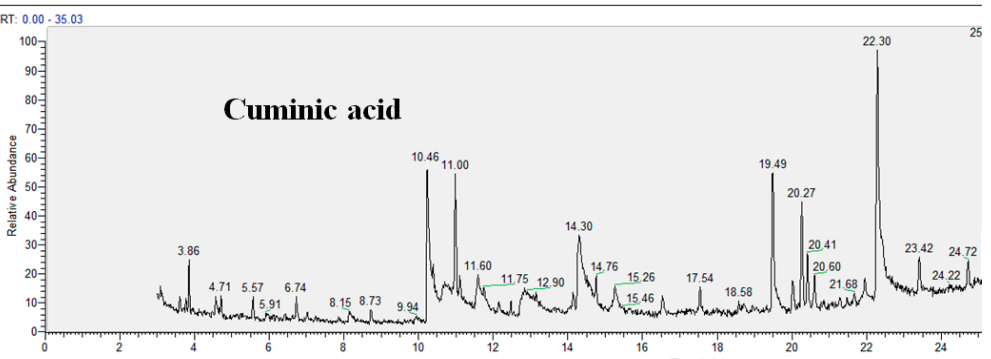

Figure 3. Detection of cuminic acid by HPLC. (A) Standard sample of cuminic acid; (B) cuminic acid in cucumber leaves from soil by irrigation; and (C) cuminic acid in cucumber roots from leaves by spraying. 


\subsection{SOD, POD, PPO, and CAT Activity}

When treated with cuminic acid, the changes in enzyme activity were different. SOD and PPO activities increased over time and were always higher than the untreated control. SOD activity reached a maximum at three days, while PPO activity reached a maximum at five days. However, POD and CAT activities decreased over time and were always lower than the control (Figure 4).

A

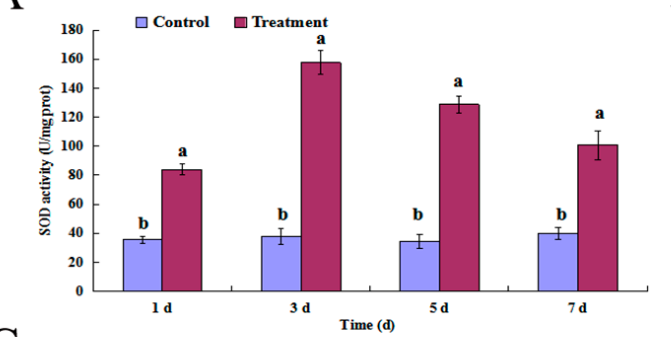

$\mathrm{C}$

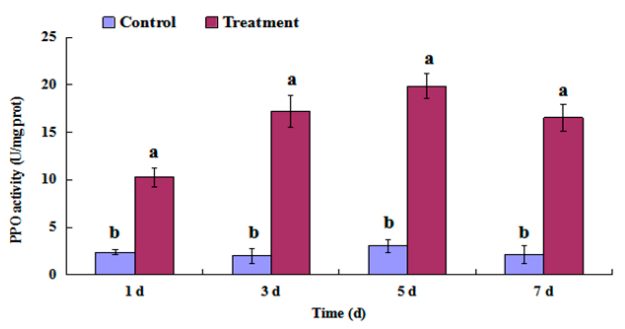

B

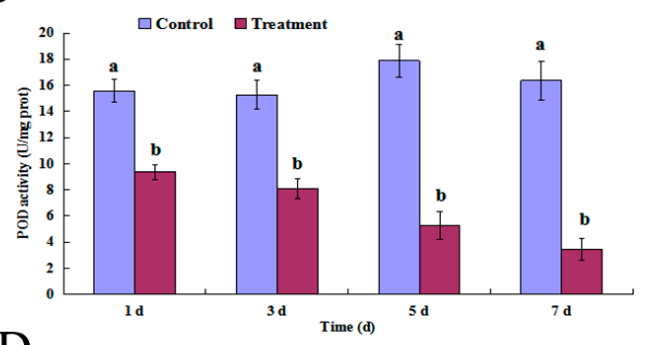

$\mathrm{D}$

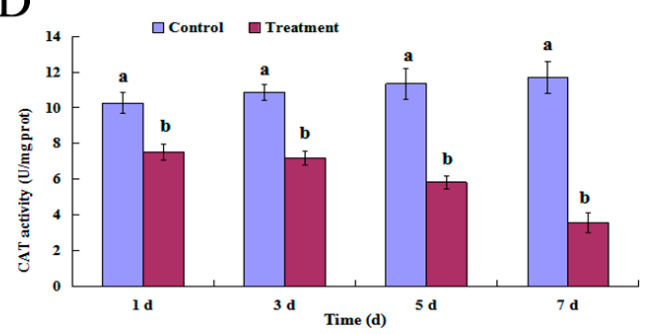

Figure 4. Detection of (A) superoxide dismutase (SOD); (B) peroxidase (POD); (C) polyphenol oxidase (PPO); (D) and catalase (CAT) activities of cucumber leaves treated with cuminic acid at $500 \mu \mathrm{g} / \mathrm{mL}$. Values are means and standard errors; $a, b$ mean values followed by different letter within the same day were significantly different in LSD tests at $p=0.05$.

\section{Discussion}

Plant diseases Fusarium wilt and anthracnose, caused by pathogenic fungi, are the most important factors that limit cucumber production worldwide, especially in China. In practice, most efforts to control the two diseases have focused on the application of synthetic chemical fungicides $[5,6]$. However, serious problems, such as handling hazards, fungicide resistance, and threats to human health and the environment, have generated concern. Therefore, looking to botanical fungicides or plant extracts has started in an attempt to find alternatives.

In our previous study, $1.2 \mathrm{~g}$ cuminic acid was extracted from $15 \mathrm{~kg}$ of Cuminum cyminum $\mathrm{L}$. seed [15]. Importantly, the toxicity test of $1 \%$ cuminic acid micro-emulsion on animals and plants, such as quail, bee, silkworm, carp, earthworm, tadpole, wheat, chili, and oilseed rape, was performed. The results were as follows: the $\mathrm{LD}_{50}$ for quail was greater than $1000 \mathrm{mg} / \mathrm{kg}$; for bees it was greater than $5000 \mathrm{mg} / \mathrm{L}$; for silkworm it was greater than $1500 \mathrm{mg} / \mathrm{L}$; for carp it was greater than $1600 \mathrm{mg} / \mathrm{L}$; for earthworm it was greater than $1000 \mathrm{mg} / \mathrm{L}$; for tadpoles it was greater than $40 \mathrm{mg} / \mathrm{L}$; and it exhibited low risk for wheat, chili, and oilseed rape [16]. All the results suggested that cuminic acid was safe and would not biologically target any sensitive species.

In the current study, the antifungal activity of cuminic acid, which was extracted from the seed of Cuminum cyminum L., was assessed. The results showed that cuminic acid has obvious inhibitory activity against F. oxysporum and C. lagenarium. Moreover, cuminic acid was more active against spore germination than mycelial growth, which was consistent with its activity against $P$. capsici [12]. However, there was no significant difference among the $\mathrm{EC}_{50}$ values for carbendazim against mycelial growth or spore germination, indicating that the mechanism of action was different between cuminic acid and carbendazim. 
In a pathogen's lifecycle, spore germination and mycelial growth are two different stages. Once infection has occurred, the suppression of mycelial growth within the host tissue becomes a major disease management target, which could interrupt the lifecycle of the pathogen [17]. In greenhouse experiments, cuminic acid at $2000 \mu \mathrm{g} / \mathrm{mL}$ exhibited over $60 \%$ protective and curative activity against F. oxysporum, which was nearly equal to the efficacy obtained by the chemical fungicide carbendazim, indicating that cuminic acid has both protective and curative activity. Therefore, it not only reduced the infection ability of the mycelia but also inhibited the spore germination. Cuminic acid was also detected in both the roots and leaves using HPLC, indicating that cuminic acid exhibits good characteristics of absorption and can be transported both upward and downward in cucumber. Cuminic acid could be used for the control of both foliar disease and root disease, which is different compared to the previous study that showed that carabrone could be only transported upward instead of downward [18].

Previous studies have demonstrated that plants have special immune sensors that can identify bacteria, viruses, fungi, and other microbial invasion. The enzyme system in plants can not only regulate the normal physiological activities, but also prevent the invasion of microorganisms $[19,20]$. In addition, salicylic acid and jasmonic acid are two important signal transmission compounds that induce plants' defense systems [21,22]. In this study, the POD and CAT activity of the cucumber leaves decreased after being treated with cuminic acid, whereas the SOD and PPO activity increased significantly after being treated with cuminic acid. Work to explore the expression of genes correlated with the pathway of salicylic acid or jasmonic acid, which is associated with the plant's defense ability, is underway in our lab.

Integrated control of fungal diseases, including biological controls and safer chemicals such as food preservatives, chitosan, and plant-derived products, has been studied [23,24]. Benzoic acid has been commonly used as food preservative and is widespread in industrial wastewater [25]. Cuminic acid, extracted from the seed of Cuminum cyminum L., belongs to the benzoic acid chemical group. However, a previous study demonstrated that cuminic acid did not target organisms, was easily degradable in soil and water, and was environmentally friendly [26].

Over several decades, crop growers have generally apply synthetic fungicides as the main method for controlling plant diseases. However, modern organic agriculture, where products cultivated without applying any chemical pesticides, is increasing in popularity [27]. Natural plant chemicals, which are the major sources of industrial and medicinal materials, including plant extracts and essential oils, have also shown potential for agricultural pest management [28,29]. For example, Vitex agnus-castus extract exhibited strong antifungal activity against Pythium ultimum in tomatoes under both in vitro and in vivo conditions [30]; Cortex Pseudolaricis extract exhibited potential antifungal activity against Colletotrichum gloeosporioides [31]; and the essential oil from Tetradium glabrifolium fruits showed larvicidal activity against Aedes albopictus [32]. In addition, glucosinolates, terpenoids, flavor compounds, and glucosinolates are receiving increased attention worldwide [33]. Previous studies demonstrated that natural products could not only be directly used as crop protection agents, but could also be used as lead compounds for the synthesis of new pesticides, such as a series of strobilurin fungicides, including azoxystrobin and picoxystrobin, which were derived based on the structure of strobilurin A [34-37]. Considering the public concern about the impact of synthetic pesticides on human health and the environment, natural products extracted from microbes, plants, and other organisms will continue to be important sources for environmentally friendlier pest management tools.

\section{Materials and Methods}

\subsection{Fungicides and Strains}

Cuminic acid (98\%) was purchased from Aladdin Bio-Chem Technology Company (Shanghai, China) and dissolved in $10 \mathrm{~mL}$ methanol to $100 \mathrm{mg} / \mathrm{mL}$ for stock solutions. Carbendazim (98\%), provided by 
Shenyang Study Institute of Chemical Industry (Shenyang, China), was dissolved in $0.1 \mathrm{~mol} / \mathrm{L}$ hydrochloric acid $(\mathrm{HCl})$ at $10 \mathrm{mg} / \mathrm{mL}$ as stock solutions.

Five F. oxysporum strains and four C. lagenarium strains (single-spore isolates) were provided by the Research and Development Center of Biorational Pesticides, Northwest A \& F University and maintained on potato dextrose agar (PDA) slants at $4{ }^{\circ} \mathrm{C}$.

\subsection{Sensitivity to Cuminic Acid}

The $\mathrm{EC}_{50}$ values of cuminic acid for the inhibition of mycelial growth were determined according to a previous study [12]. Inverted mycelia plugs, $5 \mathrm{~mm}$ in diameter, were cut from the margin of the 5-day-old colonies and then transferred to PDA plates which were amended with cuminic acid at concentrations of $0,6.25,12.5,25,50$ and $100 \mu \mathrm{g} / \mathrm{mL}$. After the plates were incubated at $25^{\circ} \mathrm{C}$ for 5 days, colony diameters in two perpendicular directions were measured and averaged. The inhibition rate of mycelial growth was calculated [12].

The activity of cuminic acid on the inhibition of spore germination was determined as per a prior study [37]. The strains were first incubated on PDA plates in the dark at $25{ }^{\circ} \mathrm{C}$ for 7 days. Then, the plates were drenched with $15 \mathrm{~mL}$ of sterile distilled water, and the spores were carefully collected from the culture surface. Spore suspensions for each strain, prepared at $1 \times 10^{5}$, were spread on water agar plates amended with cuminic acid at $0,3.125,6.25,12.5,25$ and $50 \mu \mathrm{g} / \mathrm{mL}$. After incubation at $25{ }^{\circ} \mathrm{C}$ for $10 \mathrm{~h}$, the germination of conidia was checked and the inhibition rate of spore germination was calculated. In terms of sensitivity, carbendazim was used as the control fungicide and the concentrations of carbendazim used were $0,0.3125,0.625,1.25,2.5,5,10$, and $20 \mu \mathrm{g} / \mathrm{mL}$. The experiment was conducted three times with three replicates per treatment.

\subsection{Protective and Curative Activity of Cuminic Acid in Greenhouse Experiments}

The protective activity of cuminic acid against F. oxysporum or C. lagenarium was conducted as follows [30]. One cucumber plant per pot, at a similar growth stage (three to five leaves), were irrigated with $10 \mathrm{~mL}$ of water, and carbendazim at $500 \mu \mathrm{g} / \mathrm{mL}$ or cuminic acid at 500, 1000 or $2000 \mu \mathrm{g} / \mathrm{mL}$. After $24 \mathrm{~h}$, cucumber plants were irrigated with $10 \mathrm{~mL}$ of spore suspension $\left(1 \times 10^{5}\right.$ spores $)$ collected from $F$. oxysporum, or sprayed with $10 \mathrm{~mL}$ of spore suspension $\left(1 \times 10^{5}\right.$ spores $)$ collected from C. lagenarium.

Then, the irrigated plants were kept at $25^{\circ} \mathrm{C}$ with $80 \%$ humidity in a growth chamber. All leaves from each plant and six plants for each concentration were used for the detection of anthracnose. The experiment was repeated three times. The disease indeices of Fusarium wilt and anthracnose were detected 15 days or 5 days after inoculation, respectively, and the control efficacy was calculated [8,38].

A 0-4 visual scale grade of the rhizomes and roots was used to determine the disease severity of $F$. oxysporum, where 0 represented rhizomes and roots with no symptoms, 1 denoted lesions on less than $25 \%$ of the total area, 2 denoted lesions on $25-50 \%, 3$ denoted lesions on $50-75 \%$, and 4 represented lesions on more than $75 \%$. The disease index was calculated as $100 \times[(\mathrm{n} \times 1+\mathrm{n} \times 2+\mathrm{n} \times 3+\mathrm{n} \times 4)] /(4 \times$ total assessed plants $)$, where $\mathrm{n}$ represents the number of diseased plants in that grade [38].

A $0-9$ disease severity grade was used to test the disease severity of $C$. lagenarium, which was evaluated visually on individual leaves as the percentage of diseased area. 0 represented no symptoms; 1 indicated $<1 \%, 3$ indicated $1-10 \%, 5$ indicated $10-25 \%, 7$ indicated $25-50 \%$, and 9 indicated $>50 \%$. The disease index was calculated as $100 \times[(n \times 1+n \times 3+n \times 5+n \times 7+n \times 9)] /(9 \times$ total number of examined leaves $)$, where $\mathrm{n}$ represents the numbers of leaves corresponding to the disease grade [8].

The equation to calculate control efficiency was:

Control efficacy $(\%)=[($ disease index of control - disease index of treatment) $/$ disease index of control] $\times 100$ 


\subsection{Translocation of Cuminic Acid in Cucumber Plants}

To detect the downward translocation of cuminic acid, leaves of cucumber plants were sprayed with cuminic acid at $500 \mu \mathrm{g} / \mathrm{mL}$ until runoff. After the plants were incubated in a greenhouse for 3 days, rot of the plants were cut off and ground in liquid nitrogen. After being mixed with $5 \mathrm{~mL}$ of methanol, the solution was detected using high performance liquid chromatography (Waters Alliance 2690, Waters, Milford, MA, USA) [17]. For detecting the upward translocation of cuminic acid, cucumber plants were irrigated with $10 \mathrm{~mL}$ cuminic acid at $500 \mu \mathrm{g} / \mathrm{mL}$. Then, the leaves were cut off and treated as described above. Cuminic acid (98\%) was used as the standard product. The experiment was conducted twice with four plants per treatment.

HPLC detection conditions were as follows: Hpersil BDS-C $18(4.6 \mathrm{~mm} \times 250 \mathrm{~mm}, 10 \mathrm{~mm}$, Thermo Fisher Scientific, Waltham, MA, USA) was used. Seventy percent methanol was used as the mobile phase and the flow rate was $1 \mathrm{~mL} / \mathrm{min}$ with an injection volume of $10 \mu \mathrm{L}$. The detection wavelength was $233 \mathrm{~nm}$ and the column was kept at room temperature.

\subsection{Superoxide Dismutase, Peroxidase, Polyphenol Oxidase, and Catalase Activity}

All the leaves of cucumber plants at a similar growth stage were sprayed with water and cuminic acid at $500 \mu \mathrm{g} / \mathrm{mL}$ until runoff and then kept at $25^{\circ} \mathrm{C}$ with $80 \%$ humidity. The plants were not inoculated with the pathogens. After incubation for 1, 3, 5 and 7 days, one leaf per plant was cut off (0.2 $\mathrm{g}$ per leaf) and the superoxide dismutase (SOD), peroxidase (POD), polyphenol oxidase (PPO), and catalase (CAT) activities were determined using commercial kits (Jiancheng, Nanjing, China) according to the manufacturer's instructions. Six plants per treatment were used and the experiment was repeated three times.

\subsection{Data Analysis}

Due to the variances between experiments being homogeneous, data from repeated experiments were combined for analysis. Statistical analysis was conducted using SPSS 14.0 (SPSS Inc., Chicago, IL, USA). The $\mathrm{EC}_{50}$ values of the strains were calculated by linear regression of the log of the colony diameter versus fungicide concentration. The ANOVA procedure of SPSS and Fisher's protected least significant difference $(p=0.05)$ were used to determine whether significant differences existed among the data.

\section{Conclusions}

This study demonstrated that the natural product cuminic acid not only demonstrated antifungal activity both against F. oxysporum and C. lagenarium, but also could be absorbed and transported upward and downward in cucumber. Importantly, cuminic acid altered the enzyme activities in cucumber leaves, which was consistent with our previous study that investigated the activity of cuminic acid against $P$. capsici [12]. Taken together, cuminic acid shows the potential to be used as a botanical fungicide in the management of plant diseases. Our efforts to induce cuminic acid-resistant mutants were unsuccessful, which indicated that these fungi might not readily develop resistance to cuminic acid. The work to explore the mechanism of action of cuminic acid and synthesize new compounds based on the chemical structure of cuminic acid requires further investigation.

Supplementary Materials: Supplementary materials are available online.

Acknowledgments: Support from the funding of China Postdoctoral Science Foundation (2016M592846) and National Natural Science Foundation of China (NSFC 31272074).

Author Contributions: Yong Wang, Jie Zhang and Yang Sun conducted the experiments and Yong Wang wrote the manuscript; Jie Zhang provided the material of cuminic acid and revised the manuscript; Juntao Feng and Xing Zhang conceived the whole experiment. All authors have read and approved the final manuscript.

Conflicts of Interest: The authors declare no conflict of interest. 


\section{References}

1. Wang, M.; Sun, Y.; Sun, G.M.; Liu, X.K.; Zhai, L.C.; Shen, Q.R.; Guo, S.W. Water balance altered in cucumber plants infected with Fusarium oxysporum f. sp. cucumerinum. Sci. Rep. 2015, 5, 7722. [CrossRef] [PubMed]

2. Kubo, Y. Studies on mechanisms of appressorial penetration by Colletotrichum lagenarium. J. Genet. Plant Pathol. 2005, 71, 451-453. [CrossRef]

3. Ogura, H.; Ma, J. Persistence of Fusarium oxysporum f. sp. cucumerinum in continuous cropping fields. Ann. Phytopathol. Soc. Jpn. 1992, 58, 671-676. [CrossRef]

4. Ge, Y.; Guest, D.I. Light and scanning electron microscopy studies on the infection process of melon leaves by Colletotrichum lagenarium. Physiol. Mol. Plant Pathol. 2011, 76, 67-74. [CrossRef]

5. Pavlou, G.C.; Vakalounakis, D.J. Biological control of root and stem rot of greenhouse cucumber, caused by Fusarium oxysporum f. sp. radicis-cucumerinum, by lettuce soil amendment. Crop Prot. 2005, 24, 135-140. [CrossRef]

6. Chung, S.; Kong, H.; Buyer, J.S.; Lakshman, D.K.; Lydon, J.; Kim, S.D.; Roberts, D.P. Isolation and partial characterization of Bacillus subtilis ME488 for suppression of soilborne pathogens of cucumber and pepper. Appl. Microbiol. Biotechnol. 2008, 80, 115-123. [CrossRef] [PubMed]

7. Wheeler, W.B. Role of Research and Regulation in 50 Years of Pest Management in Agriculture Prepared for the 50th Anniversary of the Journal of Agricultural and Food Chemistry. J. Agric. Food Chem. 2002, 50, 4151-4155. [CrossRef] [PubMed]

8. Chen, Y.; Dai, G. Antifungal activity of plant extracts against Colletotrichum lagenarium, the causal agent of anthracnose in cucumber. J. Sci. Food Agric. 2012, 92, 1937-1943. [CrossRef] [PubMed]

9. Isman, M.B. Botanical insecticides, deterrents, and repellents in modern agriculture and an increasingly regulated world. Annu. Rev. Entomol. 2006, 51, 45-66. [CrossRef] [PubMed]

10. Mi-Young, Y.; Byeongin, C.; Jin-Cheol, K. Recent Trends in Studies on Botanical Fungicides in Agriculture. Plant Pathol. J. 2013, 29, 1-9.

11. Copping, L.G.; Duke, S.O. Natural products that have been used commercially as crop protection agents. Pest Manag. Sci. 2007, 63, 524-554. [CrossRef] [PubMed]

12. Wang, Y.; Sun, Y.; Zhang, Y.; Zhang, X.; Feng, J.T. Antifungal activity and biochemical response of cuminic acid against Phytophthora capsici Leonian. Molecules 2016, 21, 756. [CrossRef] [PubMed]

13. Hu, L.F.; Chen, C.Z.; Yi, X.H.; Feng, J.T.; Zhang, X. Inhibition of p-isopropyl Benzaldehyde and p-isopropyl Benzoic Acid extracted from Cuminum cyminum against Plant Pathogens. Acta Bot. Boreal. Occident. Sin. 2008, 28, 2349-2354.

14. Hu, L.F.; He, J.; Feng, J.T.; Zhang, X. Optimization of supercritical $\mathrm{CO}_{2}$ extraction and characterization of antifungal activity of essential oils in Cuminum cyminum L. Aust. J. Crop Sci. 2013, 7, 1809-1813.

15. Hu, L.F.; Feng, J.T.; Zhang, X.; Zhang, Y.L. Isolation and Structure Detection of Fungicidal Components from Cuminum cyminum Seed. Chin. J. Pestic. Sci. 2007, 9, 330-334.

16. Li, T. Environmental Safety Evalution of Cumin Fungicide. Master's Thesis, Northwest A\&F University, Yangling, China, 2012.

17. Matheron, M.E.; Porchas, M. Impact of azoxystrobin, dimethomorph, fluazinam, fosetyl-Al, and metalaxyl on growth, sporulation, and zoospore cyst germination of three Phytophthora spp. Plant Dis. 2000, 84, 454-458. [CrossRef]

18. Wang, L.Y.; Wang, Y.; Han, L.R.; Wang, M.; Han, X.S.; Feng, J.T. The efficacy and translocation behavior of carabrone in wheat and cucumber. Crop Prot. 2017, 100, 87-95. [CrossRef]

19. Shen, Q.H.; Saijo, Y.; Mauch, S.; Biskup, C.; Bieri, S.; Keller, B.; Seki, H.; Ulker, B.; Somssich, I.E.; Schulze-Lefert, P. Nuclear activity of MLA immune receptors links isolate-specific and basal disease-resistance responses. Science 2007, 315, 1098-1103. [CrossRef] [PubMed]

20. Jain, A.; Singh, S.; Kumar, S.B.; Bahadur, S.H. Microbial consortium-mediated reprogramming of defence network in pea to enhance tolerance against Sclerotinia sclerotiorum. J. Appl. Microbiol. 2012, 112, 537-550. [CrossRef] [PubMed]

21. Wen, P.F.; Chen, J.Y.; Kong, W.F.; Pan, Q.H.; Wan, S.B.; Huang, W.D. Salicylic acid induced the expression of phenylalanine ammonia-lyase gene in grape berry. Plant Sci. 2005, 169, 928-934. [CrossRef] 
22. He, Y.Q.; Zhang, H.H.; Sun, Z.T.; Li, J.M.; Hong, G.J.; Zhu, Q.S.; Zhou, X.B.; Macfarlance, S.; Yan, F.; Chen, J.P. Jasmonic acid-mediated defense suppresses brassinosteroid-mediated susceptibility to rice black streaked dwarf virus infection in rice. New Phytol. 2017, 214, 388-399. [CrossRef] [PubMed]

23. Copping, L.G.; Menn, J.J. Biopesticides: A review of their action, applications and efficacy. Pest Manag. Sci. 2015, 56, 651-676. [CrossRef]

24. Ujváry, I. Transforming natural products into natural pesticides-experience and expectations. Phytoparasitica 2002, 30, 439-442. [CrossRef]

25. Karunanayake, A.G.; Todd, O.A.; Crowley, M.L.; Ricchetti, L.B.; Pittman, C.U., Jr.; Anderson, R.; Misan, T.E. Rapid removal of salicylic acid, 4-nitroaniline, benzoic acid and phthalic acid from wastewater using magnetized fast pyrolysis biochar from waste Douglas fir. Chem. Eng. J. 2017, 319, 75-88. [CrossRef]

26. Park, J.H.; Choi, G.J.; Jang, K.S.; Lim, H.K.; Kim, H.T.; Cho, K.Y.; Kim, J.C. Antifungal activity against plant pathogenic fungi of chaetoviridins isolated from Chaetomium globosum. FEMS Microbiol. Lett. 2005, 252, 309-313. [CrossRef] [PubMed]

27. Balandrin, M.F.; Klocke, J.A.; Wurtele, E.S.; Bollinger, W.H. Natural plant chemicals: Sources of industrial and medicinal materials. Science 1985, 228, 1154-1160. [CrossRef] [PubMed]

28. Calsamiglia, S.; Busquet, M.; Cardozo, P.W.; Castillejos, L.; Ferret, A. Invited review: Essential oils as modifiers of rumen microbial fermentation. J. Dairy Sci. 2007, 90, 2580-2595. [CrossRef] [PubMed]

29. Švecová, E.; Proietti, S.; Caruso, C.; Colla, G.; Crino, P. Antifungal activity of Vitex agnus-castus extract against Pythium ultimum in tomato. Crop Prot. 2013, 43, 223-230. [CrossRef]

30. Zhang, J.; Yan, L.T.; Yuan, E.L.; Ding, H.X.; Ye, H.C.; Zhang, Z.K.; Yan, C.; Liu, Y.Q.; Feng, G. Antifungal activity of compounds extracted from Cortex pseudolaricis against Colletotrichum gloeosporioides. J. Agric. Food Chem. 2014, 62, 4905-4910. [CrossRef] [PubMed]

31. Liu, X.C.; Liu, Q.; Chen, X.B.; Zhou, L.; Liu, Z.L. Larvicidal activity of the essential oil from Tetradium glabrifolium fruits and its constituents against Aedes albopictus. Pest Manag. Sci. 2015, 71, 1582-1586. [CrossRef] [PubMed]

32. Khaledi, N.; Taheri, P.; Tarighi, S. Antifungal activity of various essential oils against Rhizoctonia solani and Macrophomina phaseolina as major bean pathogens. J. Appl. Microbiol. 2015, 118, 704-717. [CrossRef] [PubMed]

33. Dayan, F.E.; Cantrell, C.L.; Duke, S.O. Natural products in crop protection. Bioorg. Med. Chem. 2009, 17, 4022-4034. [CrossRef] [PubMed]

34. Cantrell, C.L.; Dayan, F.E.; Duke, S.O. Natural products as sources for new pesticides. J. Nat. Prod. 2012, 75, 1231-1242. [CrossRef] [PubMed]

35. Gerwick, B.C.; Sparks, T.C. Natural products for pest control: An analysis of their role, value and future. Pest Manag. Sci. 2014, 70, 1169-1185. [CrossRef] [PubMed]

36. Kraiczy, P.; Haase, V.; Gencic, S.; Flindt, S.; Anke, T. The molecular basis for the natural resistance of the cytochrome $b c_{1}$ complex from strobilurin-producing basidiomycetes to center $Q_{p}$ inhibitors. FEBS J. 1996, 235, 54-63. [CrossRef]

37. Zhang, X.K.; Wu, D.X.; Duan, Y.B.; Ge, C.Y.; Wang, J.X.; Zhou, M.G.; Chen, C.J. Biological characteristics and resistance analysis of the novel fungicide SYP-1620 against Botrytis cinerea. Pestic. Biochem. Physiol. 2014, 114, 72-78. [CrossRef] [PubMed]

38. Chen, F.; Wang, M.; Zheng, Y.; Luo, J.M.; Yang, X.R.; Wang, X.L. Quantitative changes of plant defense enzymes and phytohormone in biocontrol of cucumber Fusarium wilt by Bacillus subtilis B579. World J. Microbiol. Biotechnol. 2010, 26, 675-684. [CrossRef]

Sample Availability: Samples of the compounds cuminic acid are available from the authors. 